\title{
Effect of Orlistat on the pancreas of the female albino rat: Histological and Histochemical study
}

\section{Original Article}

\author{
Soha A. Abdel Wahab, Azza H. Ali, Ahmed S. Mahmoud, Aliaa H. Abelhaleem. \\ Department of Histology \& amp;cell biology, Faculty of Medicine, Minia University, Minia, \\ Egypt
}

\begin{abstract}
Introduction: Orlistat is the only FDA approved drug for long term management of obesity. It reduces the absorption of dietary fat by inhibiting lipase enzyme. Many cases of pancreatitis were clinically reported in people who used orlistat. Aim of The work: The aim of the present study is to shed a light on the possible deleterious effect of orlistat on the normal pancreatic tissue, and the molecular mechanisms beyond these changes.

Materials \& Methods: Thirty six female albino rats were divided into 4 groups: Control Group I (a) without treatment \&I (b) received only $1 \mathrm{ml}$ fish oil. Group II received $30 \mathrm{mg} / \mathrm{kg}$ /day of orlistat dissolved in $1 \mathrm{ml}$ of fish oil orally for 8 weeks. Group III, received $40 \mathrm{mg} / \mathrm{kg}$ /day of orlistat .Group IV (a) \& (b) withdrawal groups. Pancreas was dissected out and processed for histological and immunohistochemical study for CASPASE, TNF, INOS and INSULIN.

Results: Orlistat caused variable degrees of pancreatic tissue degeneration, dilatation of pancreatic ducts with retained secretion, fatty degeneration and congestion. Inflammatory cells infiltration observed in both pancreatic acini and islets of Langerhan,s only with high dose $(40 \mathrm{mg} / \mathrm{kg})$.

Positive immunoreactivity for activated caspase 3 and iNOS being more evident in high dose and decrease in immunoreactivity for anti-insulin antibody. immunoreactivity for TNF- $\alpha$ had been shown in high dose. These effects disappear after low dose withdrawal only.

Conclusion: Orlistat may induce inflammation, fatty degeneration and impaired insulin production in the pancreas. These effects are dose dependent, and it should be taken in consideration while prescribing orlistat as a treatment for obesity.
\end{abstract}

Revised: 3 April 2017, Accepted: 4 June 2017,

Key Words: Acini, ducts, orlistat, pancreas,

Corresponding Author: Abdelwahab, Soha Abdelkawi, Tel.: 0862295774, E-mail: aspb2017@gmail.com

ISSN: 2536-9172, June 2017, Vol. 1, No 1

\section{INTRODUCTION}

Obesity is a leading preventable cause of death worldwide, with increasing rates in adults and children. Authorities consider it as one of the most serious public health problems of the $21^{\text {st }}$ century ${ }^{[1]}$. Although recently published guidelines recommend lifestyle modification as the initial treatment for obesity, still weight loss achieved with lifestyle intervention is modest ${ }^{[2]}$.

Orlistat is an anti-obesity drug that reduces the absorption of dietary fat by inhibiting lipase enzyme and is currently approved for both prescription (Xenical, Roche) and over the counter sale (Alli, GlaxoSmithKline) in the United States and Europe. Long term treatment with orlistat has been shown to significantly reduce weight and waist circumference ${ }^{[3]}$. The use of Orlistat is compromised by unpleasant gastrointestinal adverse reactions like oily stools, oily spotting and flatulence $\mathrm{e}^{[4]}$.
Acute pancreatitis is a common inflammatory process with great variability in severity. Whereas it runs a selflimiting course in most patients, in others it can take a severe form characterized by extensive necrosis leading to high mortality rates about $25 \%$ [5]

In acute pancreatitis, both exocrine and endocrine pancreatic functions are affected, depending on the extent of morphologic damage. In interstitial edematous pancreatitis, there is complete recovery of function of the gland (within 4-/12 weeks), whereas after necrotizing pancreatitis, about half the patients are left with some element of pancreatic insufficiency of varying degree of both exocrine and endocrine functions ${ }^{[6]}$.

It has been reported that there has been an association between the use of orlistat and development of pancreatitis in some cases clinically with no evidence of biliary disease or alcohol consumption ${ }^{[7]}$. 


\section{AIM OF THE WORK:}

The aim of this work is to study the histological changes that may occur in the pancreas of adult female albino rats after treatment with different doses of orlistat and try to find out the underlying mechanisms of such changes.

\section{MATERIAL AND METHODS:}

\section{Animals used:}

This study was conducted in the Histology Department of Faculty of Medicine of El- Minia University. The study was dealing with the pancreatic tissues of adult female albino rats. In this study (thirty six) female Sprague Dawley albino rats at the age 6- 8 weeks weighting 150-200 grams, specific pathogens free were used. Animals were housed in a clean plastic cage in an air conditioned room. The experiment was approved by the ethical committee for animal handling for research work in Minia University, Minia, Egypt

\section{Reagents:}

Orlistat (Xenical) $120 \mathrm{mg}$ tablets were obtained from Hoffmann-La Roche. The tablets were ground and then the different doses 30 and $40 \mathrm{mg} / \mathrm{kg}$ /day were calculated according to the interspecies dosage conversion scheme by Paget and Branes ${ }^{[8]}$. Each dose was freshly dissolved in $1 \mathrm{ml}$ of fish oil before the oral intake.

\section{Experimental design}

Animals were randomly divided into four groups as following:

\section{Group I (the control group):}

The control group included 6 rats that were subdivided into two equal subgroups:

Group Ia: rats were kept without treatment throughout the whole period of 8 weeks

Group Ib: rats received $1 \mathrm{ml}$ of fish oil orally by a gastric tube once daily for 8 weeks.

Group II (30 mg/kg orlistat treated group): This group included 6 rats each one received $30 \mathrm{mg} / \mathrm{kg} /$ day of orlistat dissolved in $1 \mathrm{ml}$ of fish oil by a gastric tube once daily for 8 weeks.

Group III (40 mg/kg orlistat treated group): This group included 6 rats each one received $40 \mathrm{mg} / \mathrm{kg}$ /day of orlistat dissolved in $1 \mathrm{ml}$ of fish oil once daily by a gastric tube for 8 weeks.

\section{Group IV (the withdrawal group):}

This group included 12 rats were subdivided into two equal subgroups:
Group IV (a): This group included 6 rats each one received $30 \mathrm{mg} / \mathrm{kg} /$ day of orlistat dissolved in $1 \mathrm{ml}$ of fish oil by a gastric tube once daily for 8 weeks, followed by 8 weeks without orlistat treatment kept only on normal diet.

Group IV (b): This group included 6 rats each one received $40 \mathrm{mg} / \mathrm{kg} /$ day of orlistat dissolved in $1 \mathrm{ml}$ of fish oil once daily by a gastric tube for 8 weeks, followed by 8 weeks without orlistat treatment and kept only on normal diet.

Rats from group I, II, and III were sacrificed after 8 weeks, while those from group IV were sacrificed after 16 weeks. All animals of all groups were sacrificed by decapitation under light halothane anesthesia. Pancreatic tissue samples were obtained for tissue preparation. The specimens were rapidly fixed in $10 \%$ formal saline for 48 hours, washed by tap water and processed to prepare tissue sections for morphological studies.

\section{For light microscopy:}

The sections (5 $\mu \mathrm{m}$ thick) were stained with haematoxylin and eosin $(\mathrm{H} \& \mathrm{E})^{[9]}$.

\section{For immunohistochemical study:}

Immunocytochemical staining was performed using polyclonal rabbit antibodies for:-

1- Tumor necrosis factor- $\alpha$ (TNF- $\alpha$ ) which is the prototypic member of a cytokine family that regulates essential biologic functions (e.g., cell differentiation, proliferation, survival and apoptosis) and a broad spectrum of responses to stress and injury (abcam ab6671).

2- Caspase 3 the key effector caspase involved in most apoptotic pathways (Thermo scientific RB1197).

3- Inducible nitric oxide synthetase enzyme (iNOS) $\mathrm{NO}$ is produced by the activity of NOS enzyme, which is involved in regulation of the rate of perfusion of the pancreatic microvasculature (Thermo scientific PA516855).

4- Insulin it is a monoclonal mouse antibody (anti insulin antibody) which were obtained from sigma Aldrich. Immunohistochemistry was performed on formalinfixed, paraffin-embedded tissue (Sigma Aldrich , EGYPT 12018).

Prior to immunolabelling, sections were deparaffinised, hydrated then washed in $0.1 \mathrm{M}$ phosphate buffer saline (PBS). Endogenous peroxidases were quenched by treatment with $\mathrm{H} 2 \mathrm{O} 2$ in methanol (Peroxidase blocking solution) followed by washing in tris buffer saline (TBS) Non-specific binding of IgG was blocked using normal goat serum, diluted $1: 50$ in $0.1 \%$ bovine serum albumin with TBS for 30 minutes.

The sections were incubated with the diluted primary antibodies (1:500) for cleaved caspase 3 for 30 minutes 
and TNF- $\alpha$ for 1hour, and anti insulin $(1: 1,000)$ for 30 minutes and iNOS(ready to use) for 1 hour at room temperature. Sections then were washed 3 times each for 5 minutes in buffer and incubated for further 30 minutes with biotinylated goat anti-rabbit secondary antibodies diluted 1:1000, followed by washing. Following further 30 minutes incubation with Vectastain ABC kits (Avidin, Biotinylated horse radish peroxidase Complex) and washing for 10 minutes. The substrate, diaminobenzidine tetra hydrochloride (DAB) in distilled water was added for 5- $10 \mathrm{~min}$.

The reaction was visualized using;Ultravsion one detection System, HRP Polymer and (diaminiobenzide) DAB Plus Chromogen (Thermo Fisher Scientific, USA). The slides were lightly counterstained by hematoxylin to gain a good morphological identification of cells, and dehydrated by passing through ascending concentrations of alcohol then cleared by xylene. Cover slip using permanent mounting media is put at last ${ }^{[10]}$.

\section{Photography:}

Slides were photographed using high-resolution color digital camera mounted on a BX51 microscope (Olympus, Japan) and connected to a computer programmed with LC micro application software in the light microscopic unit of Histology Department, Faculty of Medicine, Minia University. Images were saved as jpg and processed using adobe photoshop 7 to standardize brightness contrast and background color then printed.

\section{*Morphometric analysis for the number of anti- insulin positive Beta cells:}

Number of cells showing immuno-positive reaction for anti-insulin antibody was counted in $\mathrm{x} 40$ fields from three different slides of each animal, this was done for all experimental groups.

The morphomertrical studies were made using Leica Qwin 500 Image Analyzer computer system (Leica Microsystem Imaging Solution Ltd., Cambridge, UK) Faculty of Dentistry, Cairo University.

Statistical analysis was performed using the SPSS statistics version 19. Differences in the mean of continuous variables were analyzed using parametric test (ANOVA) and Post hoc test ${ }^{[11]}$. The values $\mathrm{P} \leq 0.05$ were regarded statistically significant.

\section{RESULTS}

Histological study of pancreas using hematoxylinn and eosin:

The pancreatic sections of the control group (Groups Ia and Ib) exhibited normal lobular architecture with abundant islets of Langerhan,s interspersed among the pancreatic exocrine acini. The islets appeared lightly stained than the surrounding acinar cells (Fig.1).
The pancreatic acini were closely packed and separated from each other by very little connective tissue. Each acinar cell had basal basophilia and apical acidophilia. The nuclei appeared rounded and towards the base. Interlobular ducts were found between lobules, within the intact connective tissue septa. They vary considerably in size. The smaller forms have a cuboidal epithelium (Fig.2).

Each islet consisted of lightly stained polygonal cells arranged in cords separated by a network of blood capillaries (Fig.3).

In group II ( $30 \mathrm{mg} / \mathrm{kg}$ Orlistat treated group) there were focal areas that showed appearance of vacuoles in the cytoplasm of the acinar cells (Fig.4a \& 4b).

The inter-lobular pancreatic ducts showed dilatation, retained secretion and their lining epithelial cells were flattened (Fig.5a \& 5b).

\section{In group III ( $40 \mathrm{mg} / \mathrm{kg}$ orlistat treated group)}

There were marked changes in the acinar cells in some areas. It was found that parts of pancreatic lobules were completely replaced by vacuolated cells and infiltrated by inflammatory cells. The vacuolated cells had the histological features of adipocytes. Pycknotic cells were also found (Fig.6a \& 6b).

Dilated inter- lobular pancreatic ducts with retained secretion were detected, there was discontinuation of the lining epithelium and the epithelial cells were mostly with flat nuclei while others possessed rounded ones. Some intra lobular ducts had retained secretion and were surrounded by inflammatory infiltrate (Figs $7 \& 8$ ). Some islets of Langerhan,s showed inflammatory cell infiltration and congested blood capillaries (Fig.9)

\section{Immunohistochemical results:}

*Immunohistochemical study of the rat pancreatic tissues using activated (cleaved) Caspase 3: No detectable immunolabeling for activated caspase- 3 in the pancreatic sections of the control group (Fig.10).

In group II (30 mg/kg Orlistat treated group), there was positive reaction for active caspase 3 in the rat pancreas. The acinar cells showed cytoplasmic expression of active caspase 3 (Fig. 11).

Group III (40mg/kg treated group) showed obvious immunoreactivity for activated caspase 3 in the acinar cells. The expression in the acini showed a pattern of heterogeneity; some of the acinar cells had shown both cytoplasmic and nuclear expression while others showed only cytoplasmic expression (Fig.12).

*Immunohistochemical study of the ratpancreatic tissues using TNF- $\alpha$ : There was Negative immunoreactivity for TNF- $\alpha$ in pancreatic sections of the control group (Fig. 13). 
In group II (30 $\mathrm{mg} / \mathrm{kg}$ Orlistat treated group): no immunoreactivity for TNF- $\alpha$ was detected in the Pancreatic sections (Fig.14).

In group III (40mg/kg treated group), Some acinar cells showed positive immunoreactivity for TNF- $\alpha$ (Fig.15). Some cells within connective tissue septa showed expression for TNF- $\alpha$ which were most probably macrophages (Fig.16).

*Immunohistochemical study of the rat pancreatic tissues using iNOS: Sections of the control group displayed negative iNOS immunoreactivity in the pancreatic tissue. (Fig. 17).

In group II (30 mg/kg Orlistat treated group): there were faint expression of iNOS in the pancreatic tissue. Sections of this group displayed positive immunoreactivity in the cytoplasm of some of the acinar cells. iNOS expression was also found in endothelial cells of the blood capillaries (Fig.18). Some peripheral cells in the islets of Langerhan, $\mathrm{s}$ showed faint positive expression for iNOS (Fig. 19).

In group III (40mg/kg treated group) displayed faint expression of iNOS in the cytoplasm of most of the acinar cells, with some nuclear expression. The cytoplasm of some of the islet cells also showed iNOS positive expression (Figs $20 \& 21$ ).

*Immunohistochemical study of the rat pancreatic tissues using anti-insulin antibody: $\beta$-cells of the control group showed strong positive reaction for anti-insulin antibody as brown granules occupying the cytoplasm of most of the $\beta$-cells (Fig. 22).

In group II (30 mg/kg Orlistat treated group), the immunoreactivity for anti-insulin antibody was markedly decreased (Fig.23).

In group III (40mg/kg treated group), most of $\beta$-cells had shown no " immunoreactivity for anti-insulin antibody (Fig. 24).

\section{Withdrawal groups results:-}

\section{Hematoxyline and eosine results:-}

In the withdrawal group (IV a)
The pancreatic tissue of the rats kept on $30 \mathrm{mg} / \mathrm{kg}$ orlistat for 8 weeks followed by 8 weeks without treatment showed complete recovery with normal histological picture of acini, ducts and islets (Fig 25).

Group (IV b) kept on 40mg/kg daily oral dose of orlistat followed by 8 weeks without treatment; the exocrine pancreas showed vacuolation of the cytoplasm of some acini, dilated interlobular ducts with retained secretion (Fig 26 A), the connective tissue septa showed inflammatory cell infiltration which also invaded the islets of Langerhan,s (Fig.26 B).

\section{Immunohistochemical results:-}

Withdrawal group IV a $(30 \mathrm{mg} / \mathrm{kg}$ orlistat for 8 weeks followed by 8 weeks without treatment) the pancreatic tissue of this group showed negative expression for caspase-3 (Fig.27), and nearly negative expression for iNOS (Fig. 28), while anti-insulin antibody showed strong positive immuno-reaction in nearly all $\beta$-cells (Fig. 29).

Withdrawal group IV b $(40 \mathrm{mg} / \mathrm{kg}$ orlistat for 8 weeks followed by 8 weeks without treatment) showed weak cytoplasmic expression of caspase-3 (Fig. 30), positive cytoplasmic expression for iNOS in few peripheral cells of Islets of Langerhan,s iNOS (Fig.31) anti-insulin antibody showed nearly normal expression in all $\beta$-cells (Fig. 32).

\section{*Morphometric analysis for the number of anti- insulin positive Beta cells:}

Statistical analysis was performed using the SPSS statistics version 19. Differences in the mean of continuous variables were analyzed using parametric test (ANOVA) and Post hoc test. The values $\mathrm{P} \leq 0.05$ were regarded statistically significant.

There was a significant decrease in the number of insulin producing cells in group (II) $30 \mathrm{mg}$ orlistat treated group and group III (40mg orlistat treated group) versus control group.

There was no significant difference in the number of insulin producing cells between $30 \mathrm{mg}$ orlistat treated group and 40mg orlistat treated group (Table1).

Table1: showing the significant decrease in the number of insulin producing cells after orlistat treatment.

\begin{tabular}{lcccccc}
\hline $\begin{array}{l}\text { Insulin } \\
\text { expression }\end{array}$ & Control group & $\begin{array}{c}30 \mathrm{mg} / \mathrm{kg} \text { orlistate } \\
\text { treated group }\end{array}$ & $\begin{array}{c}40 \mathrm{mg} / \mathrm{kg} \text { orlistate } \\
\text { treated group }\end{array}$ & p-value \\
\hline & & & & & $0.001^{*}$ \\
& & & & & & \\
Mean \pm SD & $103.8 \pm 3.9$ & $25.2 \pm 2.6$ & $23.4 \pm 3.4$ & I vs II & I vs III & II vs III \\
& & & $0.001^{*}$ & $0.001^{*}$ & 0.7 \\
\hline
\end{tabular}

*significant 


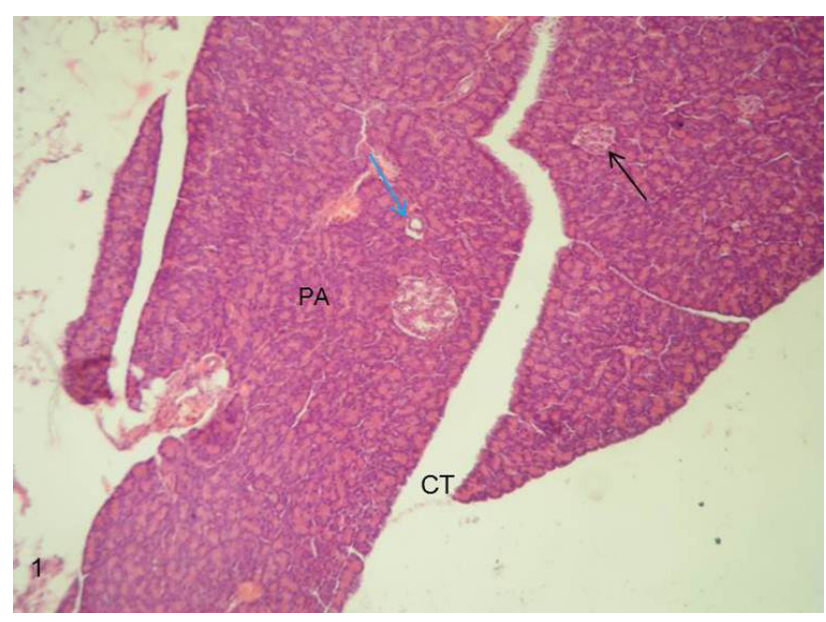

Fig. 1: A Photomicrograph of rat pancreatic tissue of the control group showing normal lobular architecture. Islets of Langerhans (black arrows) seen surrounded by the pancreatic acini (PA). Notice the Interlobular connective tissue (CT) and the interlobular duct (blue arrow). $(\mathrm{Hx} \& \mathrm{E} \mathrm{x} 100)$

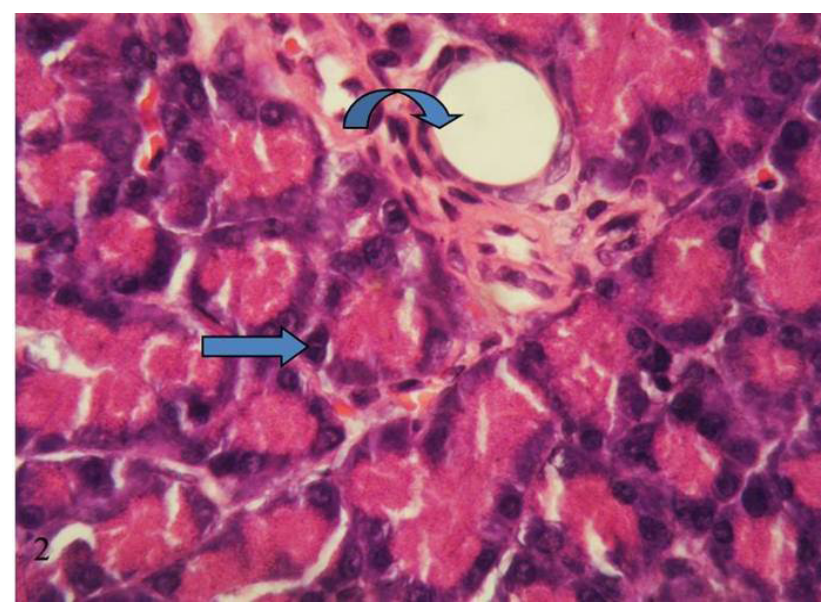

Fig. 2: A photomicrograph of rat pancraetic tissue of the control group showing normal pancreatic acini with basal basophilia and apical acidophilia and basal rounded nuclei (arrow) Notice the normal interlobular duct, between the lobules (curved arrow).

(H\&EX1000).

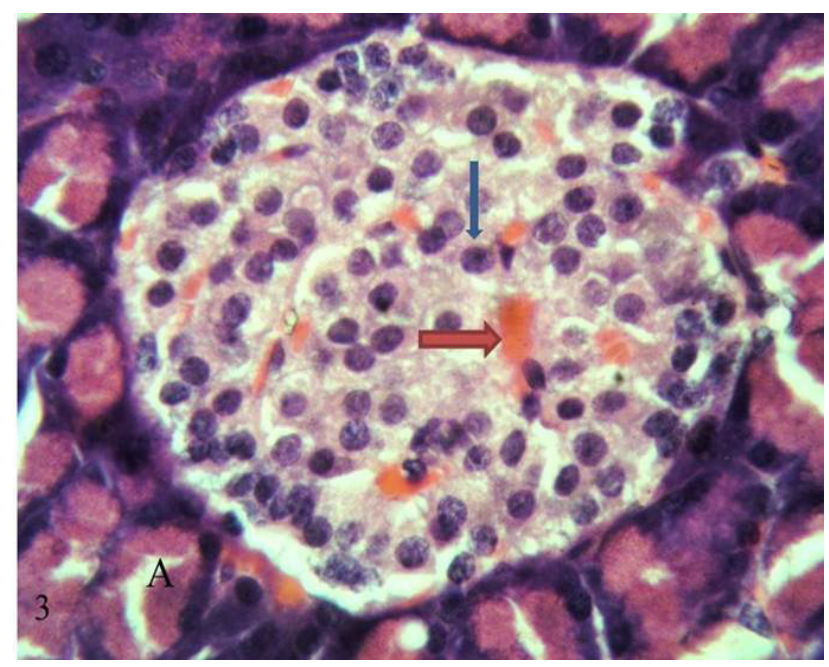

Fig. 3: A photomicrograph of rat pancreatic tissue of the control group showing Islet's cells (blue arrows) forming cords separated by a network of blood capillaries (red arrow). Notice the pancreatic acini with its basal basophilia and apical acidophilia (A).

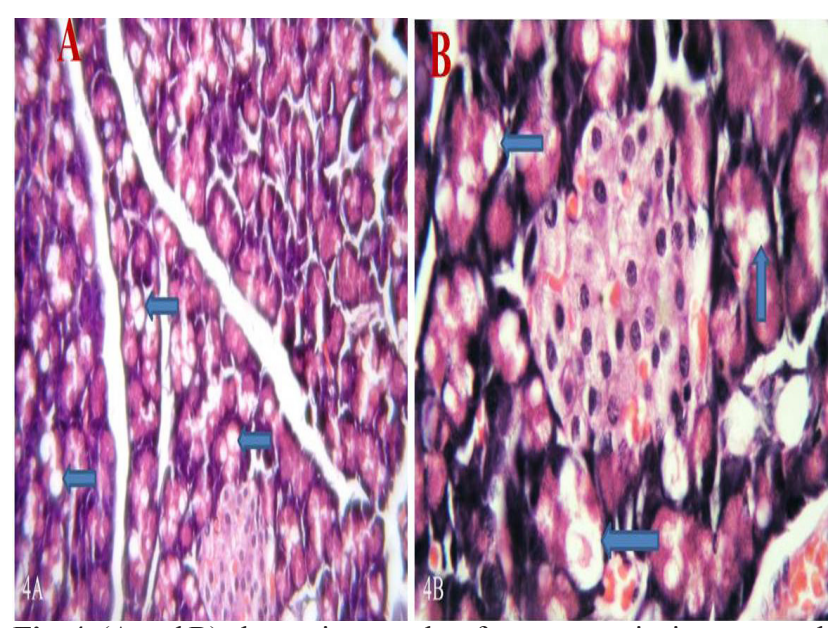

Fig. 4: (A and B) photomicrographs of rat pancreatic tissue treated with $30 \mathrm{mg}$ orlistat group II showing appearance of vacuoles in the cytoplasm of acinar cells. (arrows). (H\&E, Ax400, Bx1000).

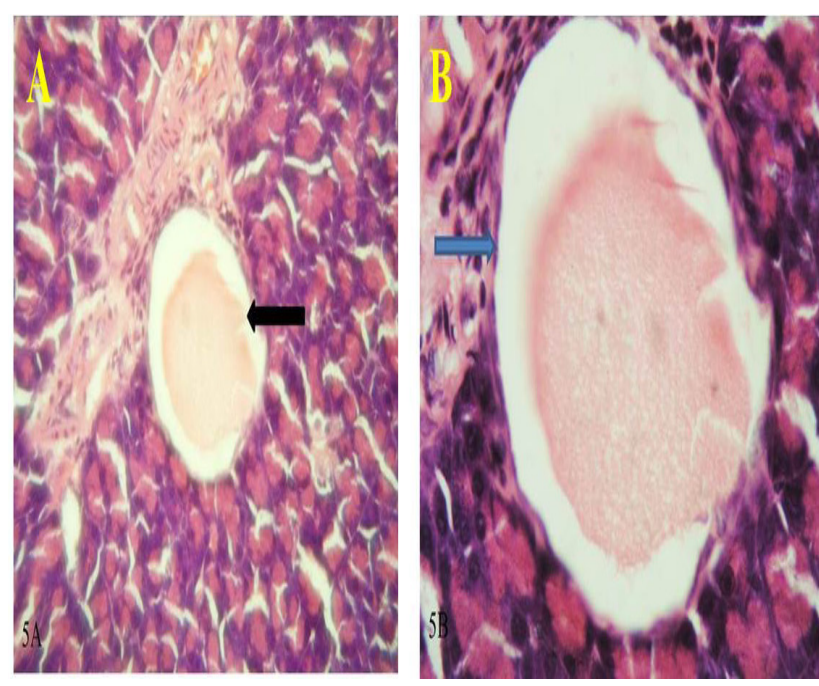

Fig. 5: (A) A photomicrograph of rat pancreatic tissue treated with $30 \mathrm{mg}$ orlistat group II showing dilated pancreatic duct with retained secretion (black arrow). (B) A higher magnification showing flattened lining epithilial cells of the dilated duct (arrow) (H\&E, Ax400, Bx1000).
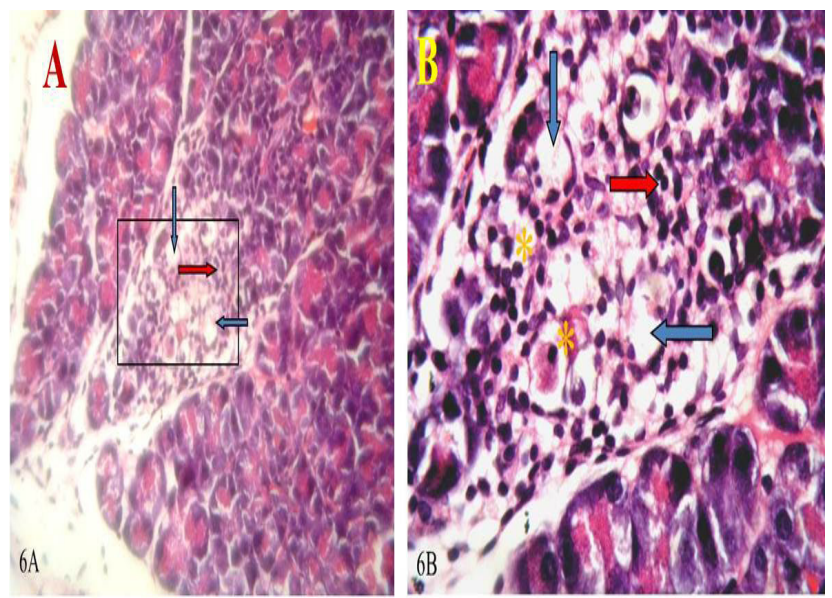

Fig. 6: (A) A photomicrograph of rat pancreatic tissue treated with $40 \mathrm{mg}$ orlistat group III showing replacement of part of pancraetic lobule (rectangle) with vaculated cells (blue arrows) and inflammatory infilterate (red arrow). (B) A higher magnification of figure (a) The vacuolated cells show the histological features of apoptotic cells with pycknotic nuclei (asterisk).
(H\&E, Ax400, Bx1000). 


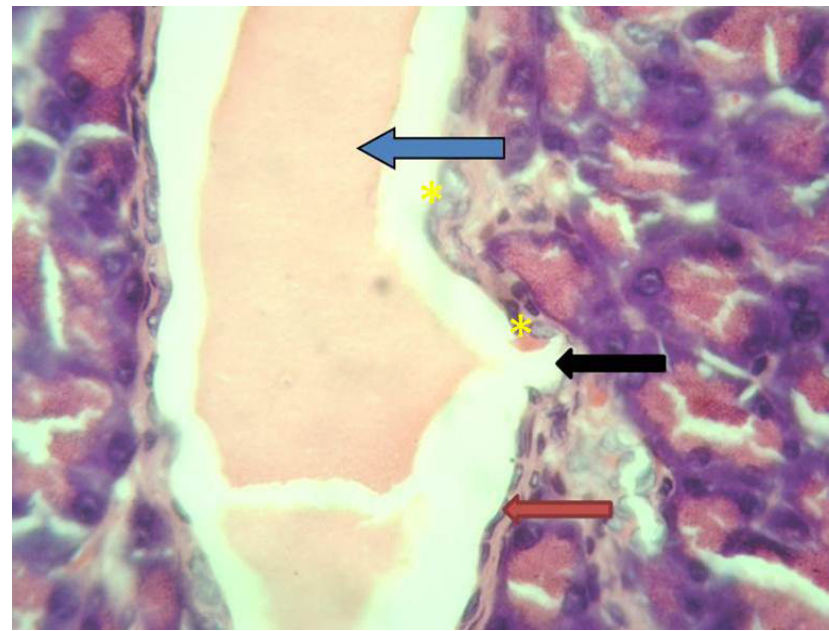

Fig. 7: A photomicrograph of rat pancreatic tissue treated with $40 \mathrm{mg}$ orlistat group III showing dilated inter-lobular duct with retained secretion (blue arrow), lined with epithilial cells having flat nuclei (red arrow) while others have rounded one $(*)$. Notice the discontinuation of the epithelial lining (black arrow).

(H\&E. x1000).

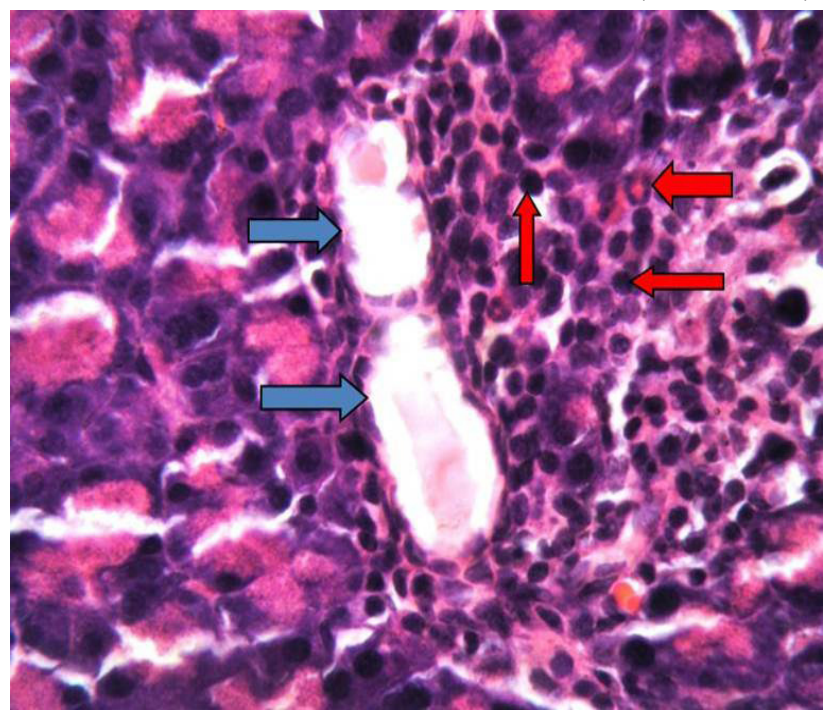

Fig. 8: A photomicrograph of rat pancreatic tissue treated with 40 $\mathrm{mg}$ orlistat (group III) showing intralobular ducts with retained secretion (blue arrows) surrounded by inflammatory infilterate (red arrows).

(Hx\&E, Ax400, Bx1000).

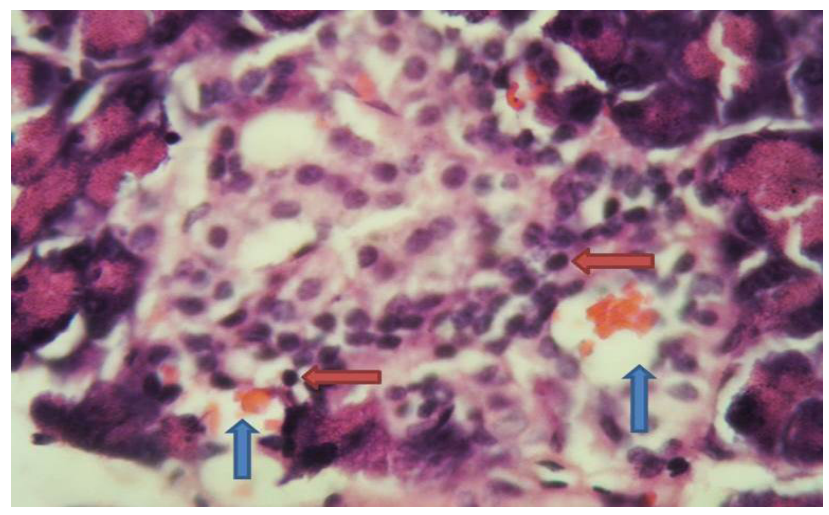

Fig. 9: A photomicrograph of rat pancreatic tissue treated with $40 \mathrm{mg}$ orlistat (group III) showing intralobular congested blood capillaries around the pancreatic islets (blue arrows) and inflammatory infilterate within the islets (red arrows).

(Hx\&E, x1000)..

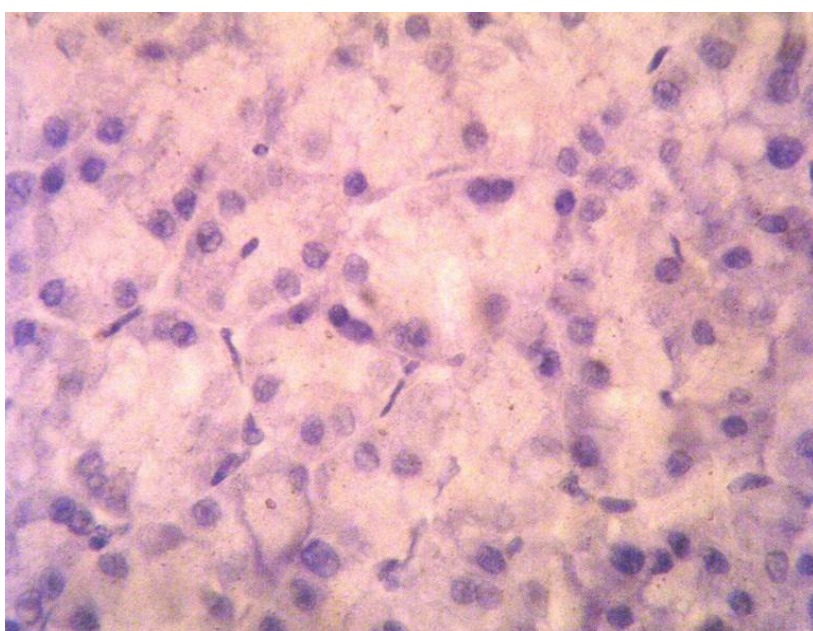

Fig. 10- A photomicrograph of the rat pancreatic tissue of the control group I: showing negative immune reaction for caspase-3 in the acinar cells (caspase-3 immuno-staining with counter stain hematoxylin x1000).

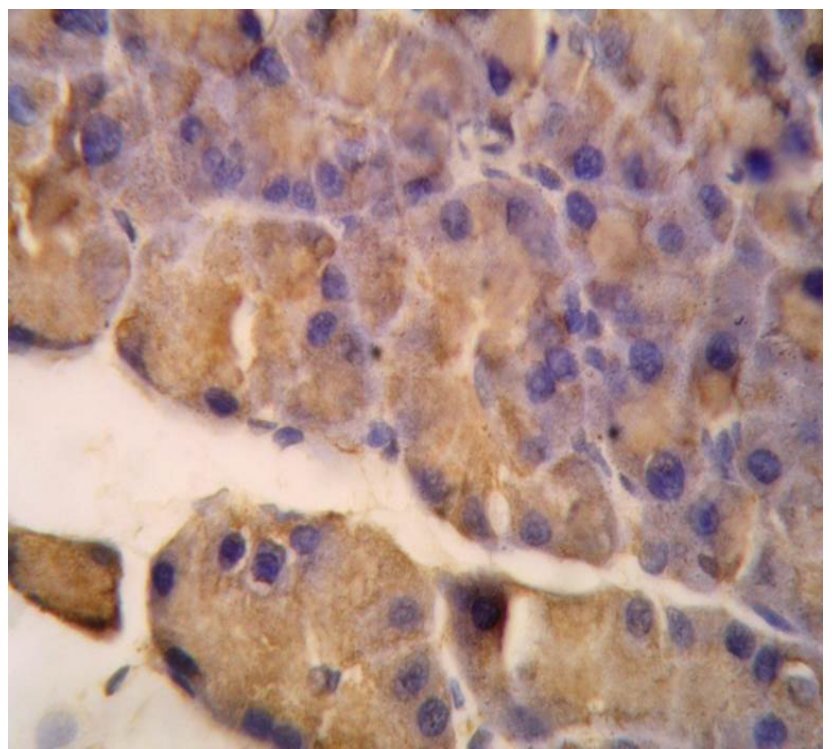

Fig. 11: A photomicrograph of rat pancreatic tissue treated with $30 \mathrm{mg}$ orlistat group II showing positive immuno reaction for caspase- 3 in the cytoplasm of the acinar cells.

(caspase-3 immuno-staining with counter stain hematoxylin

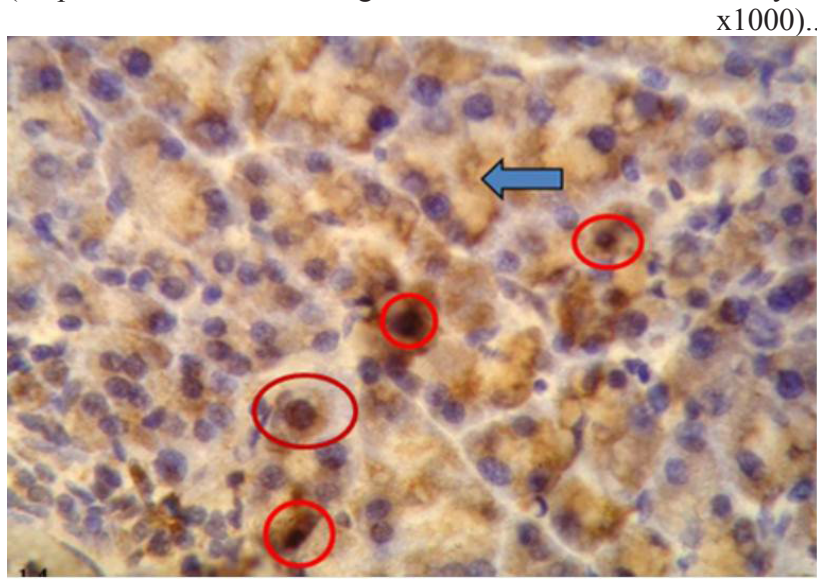

Fig. 12: A photomicrograph of rat pancreatic tissue treated with $40 \mathrm{mg}$ orlistat (group III) showing positive immuno reaction for caspase- 3 in the cytoplasm of the acinar cells (arrow). Notice nuclear expression in some acinar cells (red circles). ( Cspase-3 immunostaining with counter stain hematoxylin

$\mathrm{x} 1000)$.. 


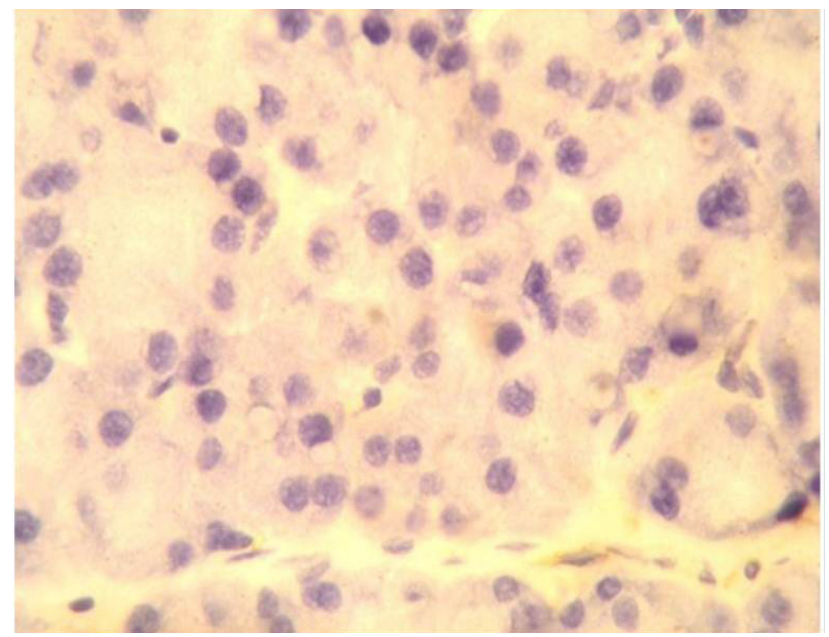

Fig. 13: A Photomicrograph of rat pancreatic tissue of the control groupI showing negative immune reaction for TNF-alpha in the acinar cells.(TNF-alpha immunostaining with counter stai hematoxylin $\mathrm{x} 1000)$..

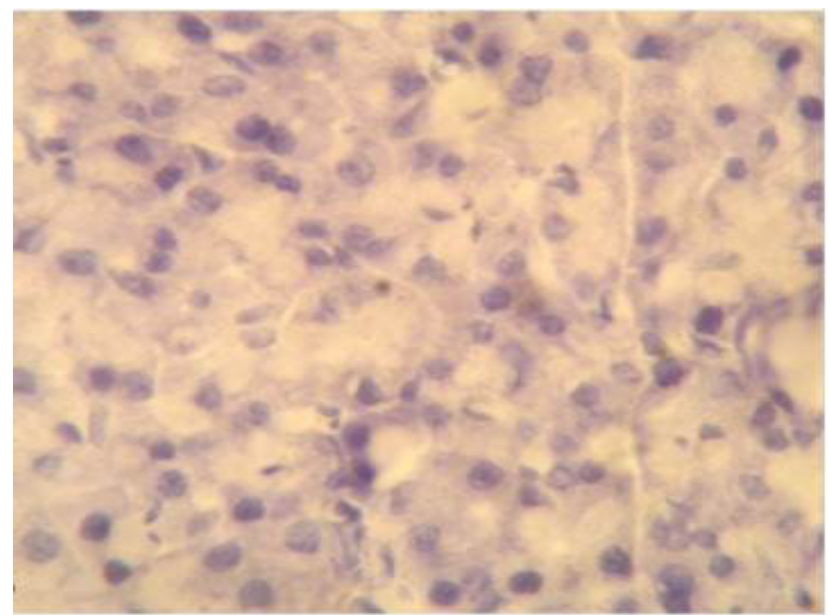

Fig. 14: A Photomicrograph of rat pancreatic tissue treated with $30 \mathrm{mg}$ orlistat( group II) showing negative immune reaction for TNF- $\alpha$ in the acinar cells. (TNF- $\alpha$ mmunostaining with counter stain hematoxylin. $\mathrm{x} 1000)$..

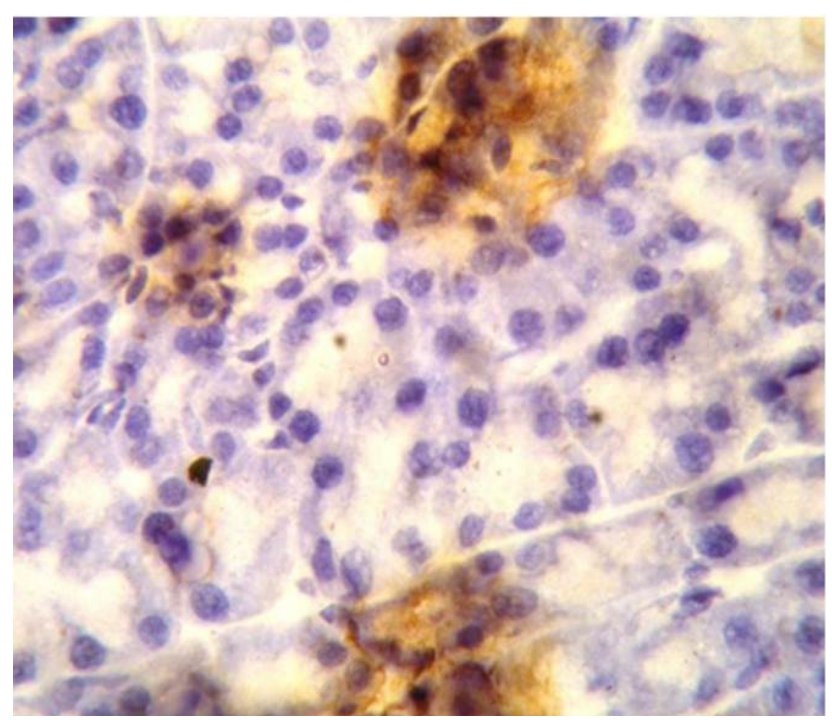

Fig. 15: A Photomicrograph of rat pancreatic tissue treated with $40 \mathrm{mg}$ orlistat (groupIII) showing positive immuno reaction for TNF- $\alpha$ in some acinar cells (TNF- $\alpha$ immunostaining with counter stain hematoxylin.

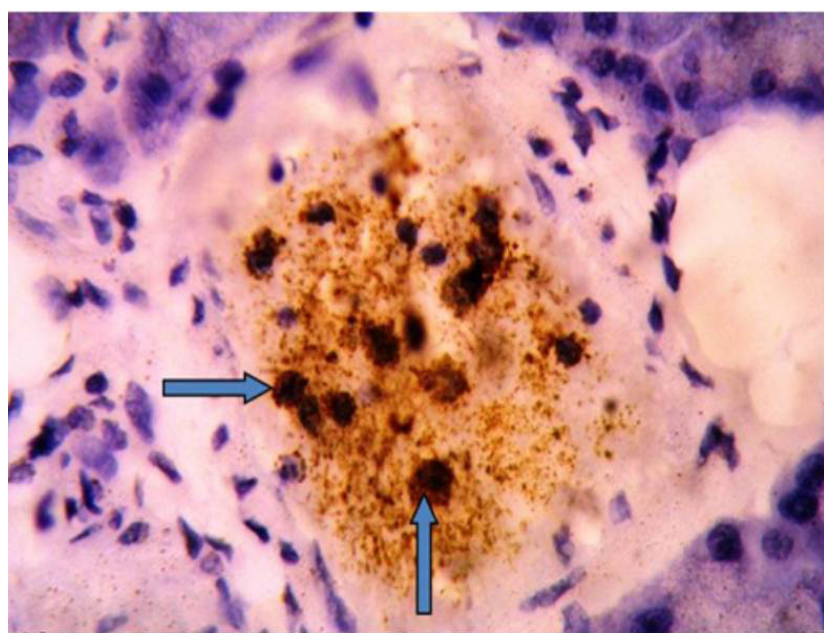

Fig. 16: A Photomicrograph of rat pancreatic tissue treated with $40 \mathrm{mg}$ orlistat(group III) showing positive immuno reaction for TNF- $\alpha$ in some cells within connective tissue septa most probably macrophages (arrows). (TNF- $\alpha$ immunostaining counter stain $\mathrm{H}$

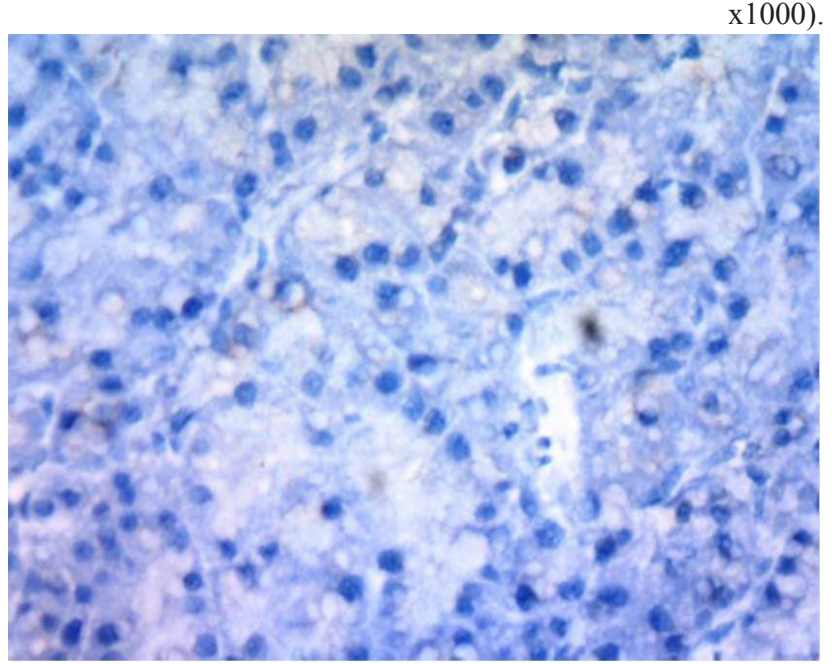

Fig. 17: A Photomicrograph of rat pancreatic tissue of the control groupI showing negative immune reaction for iNOS in the acinar cells.( iNOS immunostainig with counter stain hematoxylin $\mathrm{x} 400$ )

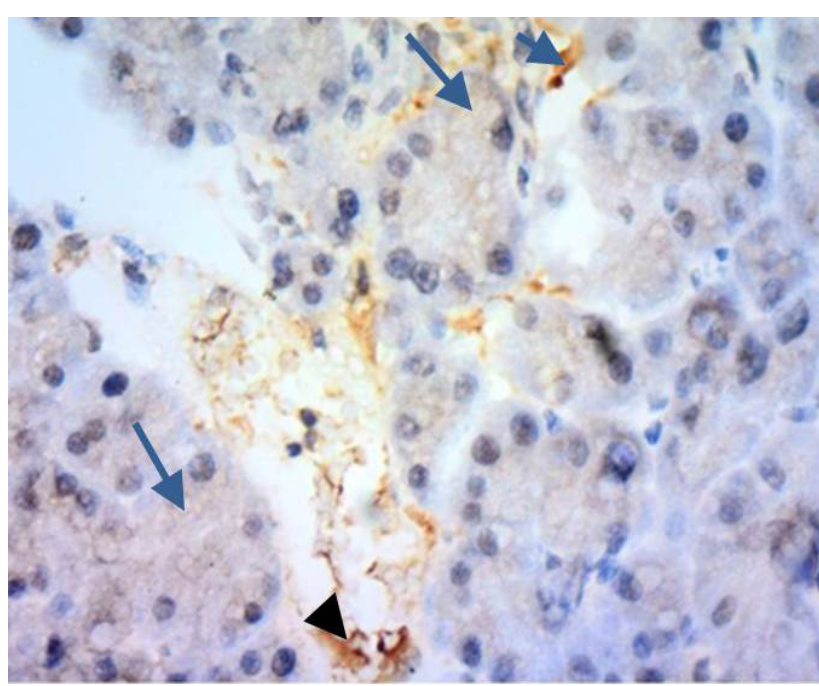

Fig. 18:.A Photomicrograph of rat pancreatic tissue treated with $30 \mathrm{mg}$ orlistat (group II) showing weak immuno reaction for iNOS in the cytoplasm of the acinar cells (arrow). Notice iNOS expression in endothelial cells of blood capillaries. (arrowhead). (iNOS immunostaining with counter stain hematoxylin. $\mathrm{x} 400$ ). 


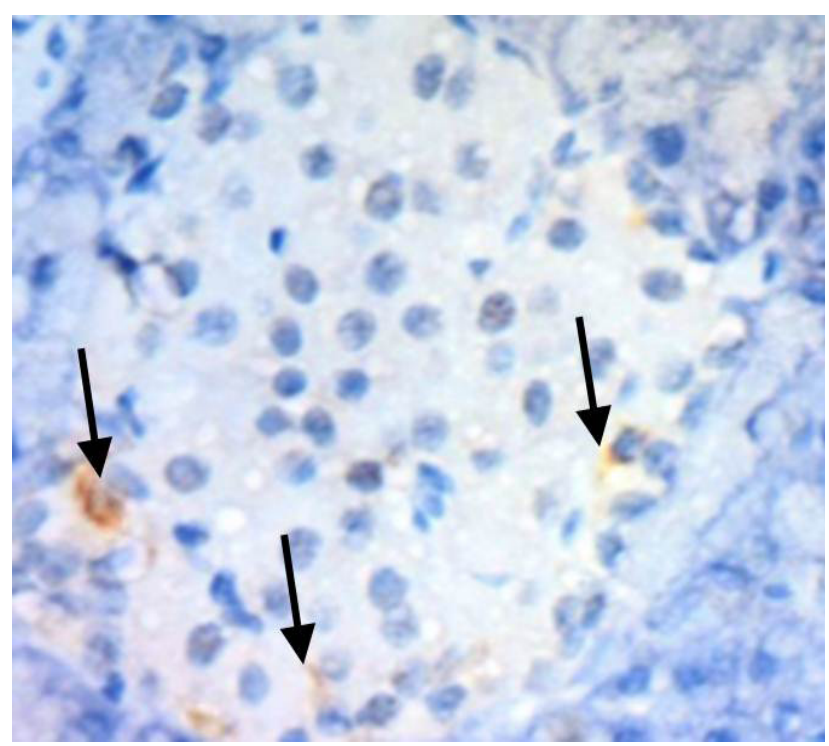

Fig. 19: A Photomicrograph of rat pancreatic tissue treated with $30 \mathrm{mg}$ orlistat (group II) showing weak immuno reaction for iNOS in the cytoplasm of some peripheral cell islets of Langerhans (arrow).

(iNOS immunostaining with counter stain hematoxylin $\mathrm{x} 400$ ).

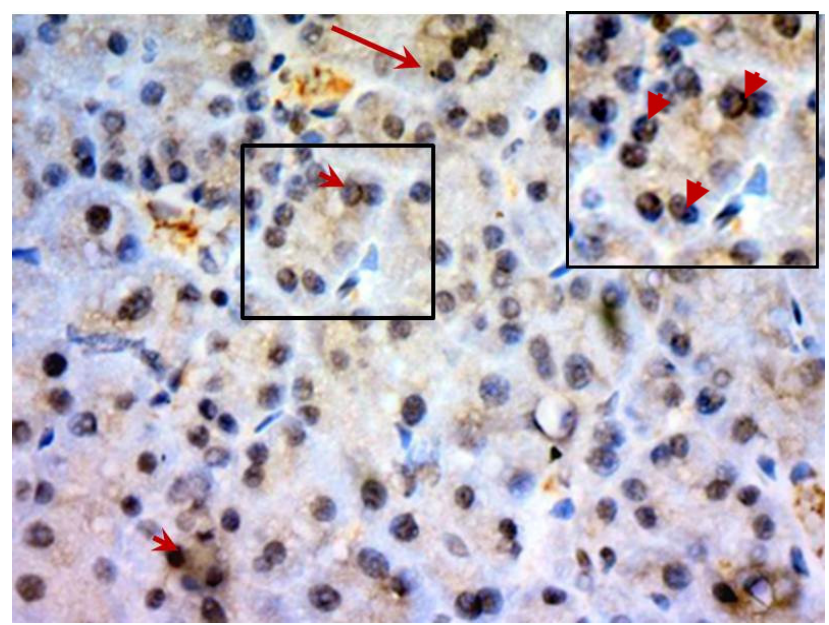

Fig. 20: A photomicrograph of rat pancreatic tissue treated with $40 \mathrm{mg}$ orlistat(group III) showing positive immuno reaction for iNOS in the cytoplasm of the acinar cells (arrow) (iNOS immunostaining with counter stain hematoxylin $\mathrm{x} 400$ ) Insert is higher magnification (x1000) showing nuclear translocation of the expression of iNOS in some acini (arrow head).

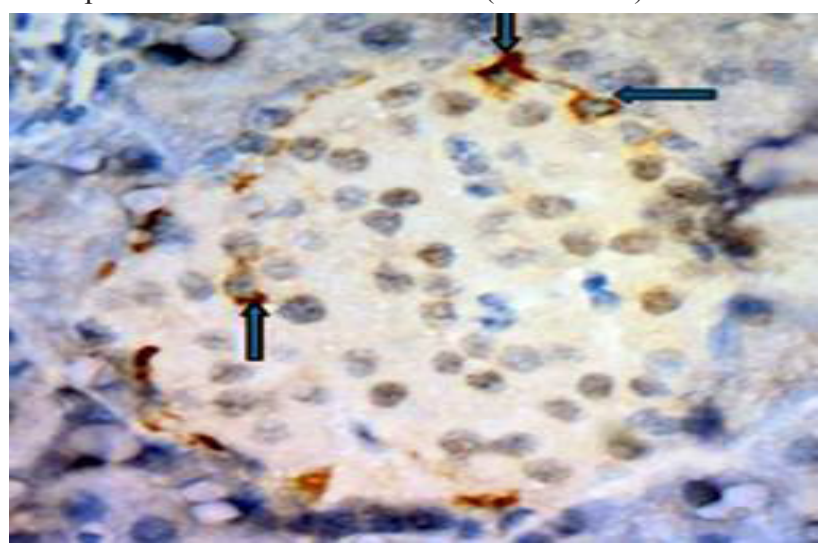

Fig. 21: A photomicrograph of rat pancreatic tissue treated with $40 \mathrm{mg}$ orlistat (group III) showing positive immuno reaction for iNOS in the cytoplasm of some islet peripheral cells (arrow) (iNOS immunostaining with counter stain hematoxylin.x 1000) .

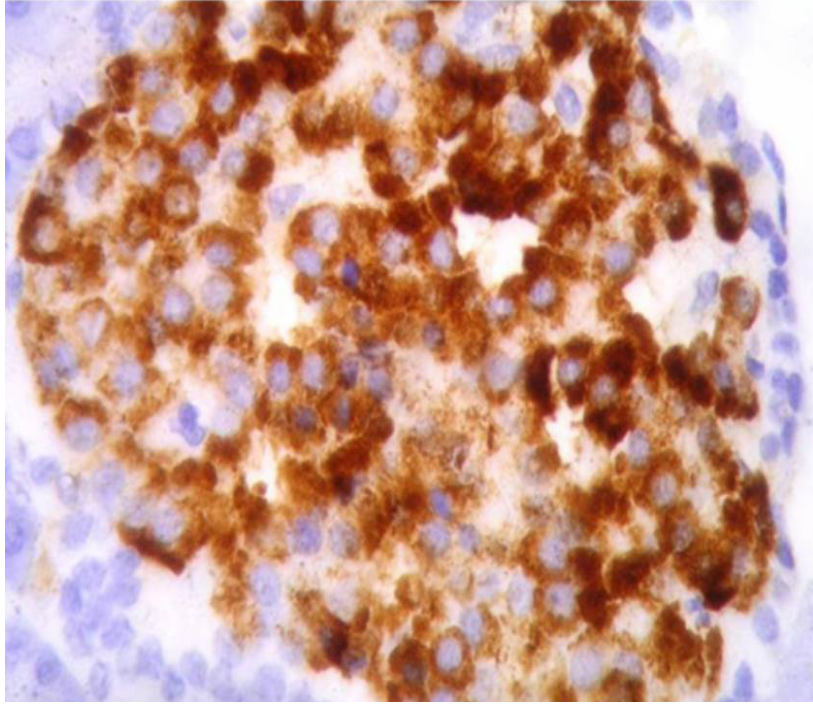

Fig. 22: A photomicrograph of rat pancreatic islet cells of the control Group showing positive immunostaining for insulin in $\beta$-cells

(Immunostaining for insulin withcounter stain hematoxylin $\mathrm{x} 1000)$.

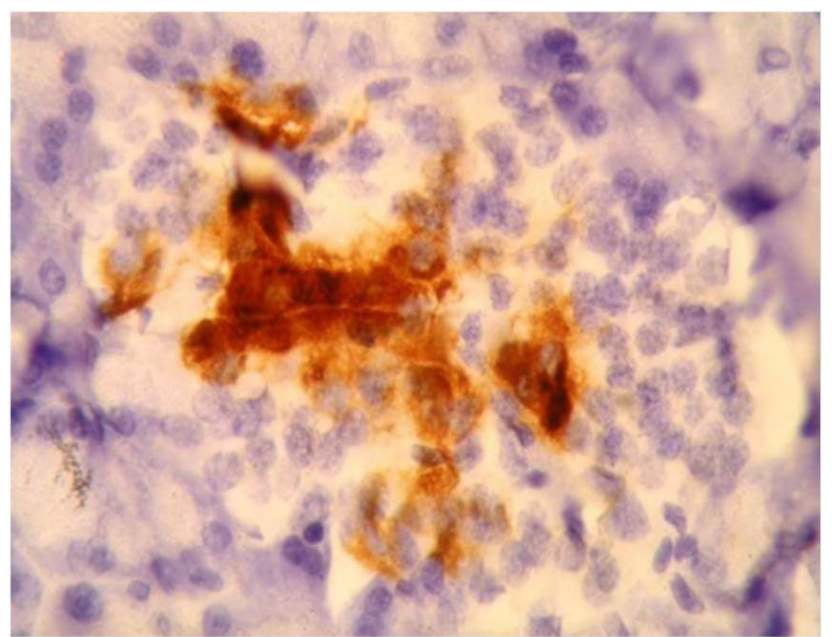

Fig. 23: A photomicrograph of rat pancreatic islet cells treated with $30 \mathrm{mg}$ orlistat(group II) showing decrease in the immunostaining of $\beta$-pancreatic cells

(immunostaining for insulin with counter stain hematoxylin $\mathrm{x} 1000)$

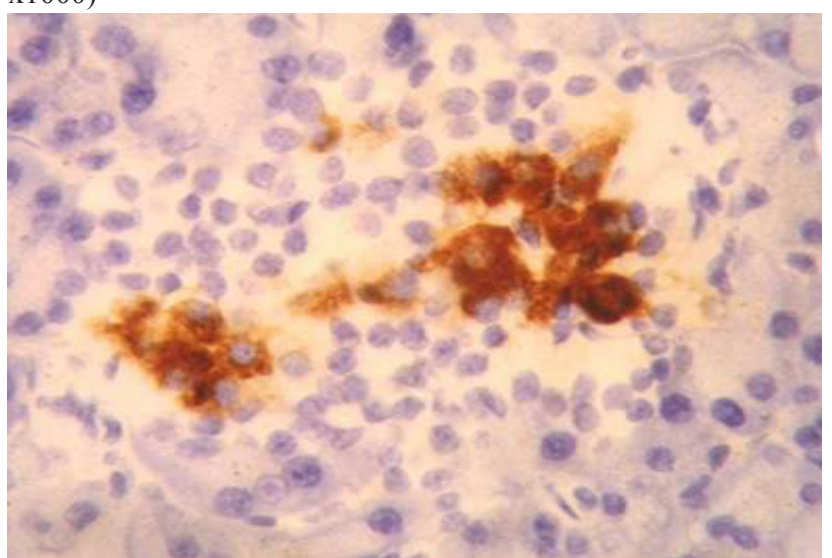

Fig. 24: A photomicrograph of pancreatic islet cells treated with $40 \mathrm{mg}$ orlistat showing decrease in immunostaining for insulin in $\beta$-pancreatic cells.

(immunostaining for insulin with counter stain hematoxylin 1000). 

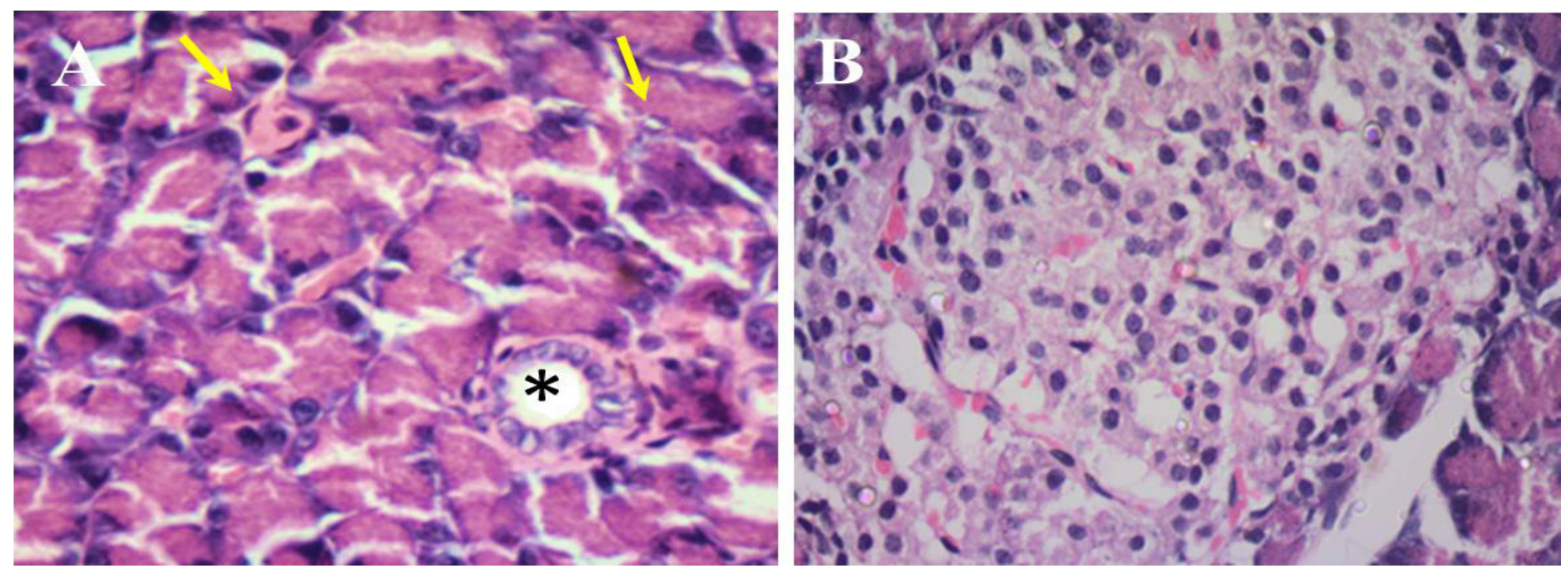

Fig. 25 (A\&B): A photomicrograph of the pancreatic tissue of withdrawal group IV a orlistat $30 \mathrm{mg} / \mathrm{kg}$ for 8 weeks followed by 8 weeks without treatment) Showing(A) normal pancreatic acini (arrow). Notice the intrelobular duct showing normal size and columnar lining epithelium $\left(^{*}\right)(B)$ Normal histological structure of islets of langerhan,s.

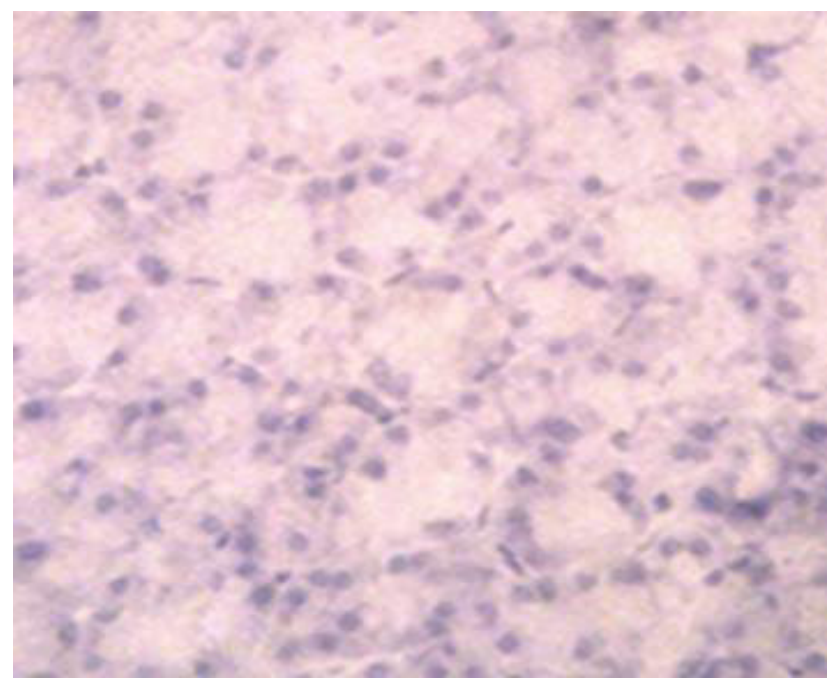

Fig. 26: A Photomicrograph of the rat pancreatic tissue of group IV (b) showing :- (A) dilated interlobular duct with retained secretion (arrow) and congested blood vessel close to the dilated duct (arrowhead) (A) the presence of inflammatory cells in the connective tissue septa(arrow) some of these inflammatory cells invading the boundaries of the islets of Langerhan,s. arrow head).

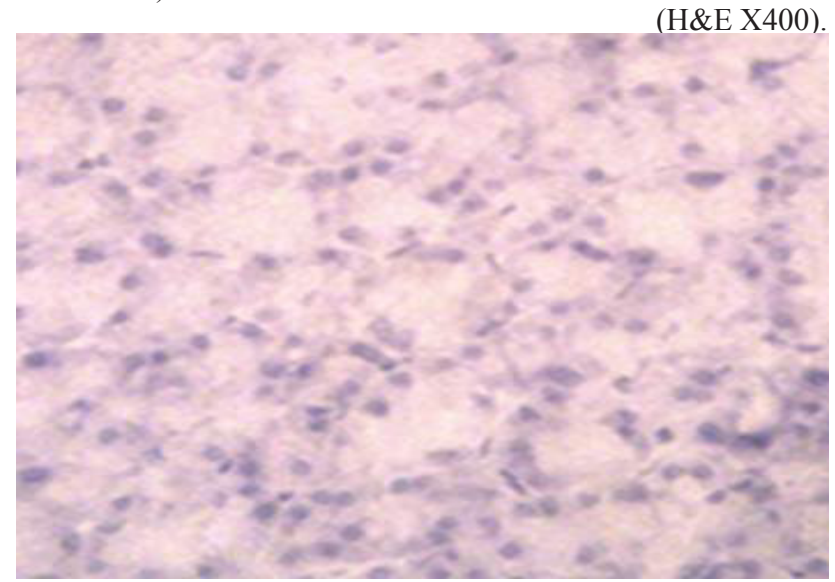

Fig. 27: A photomicrograph of the pancreatic tissue of withdrawal group IV a (orlistat $30 \mathrm{mg} / \mathrm{kg}$ for 8 weeks followed by 8 weeks without treatment) showing negative expression of caspase-3. (immunostaining for caspase-3 with counter stain hematoxylin.

$\mathrm{X} 400)$.

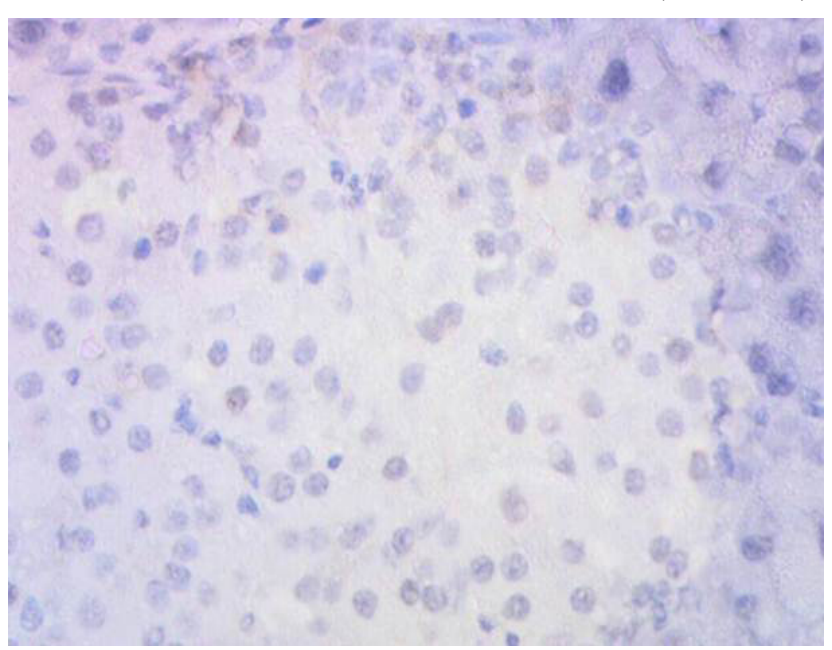

Fig. 28: A photomicrograph of the pancreatic tissue of withdrawal group IV a (orlistat $30 \mathrm{mg} / \mathrm{kg}$ for 8 weeks followed by 8 weeks without treatment) showing nearly negative expression for iNOS. (immunostaining for caspase-3 with counter stain hematoxylin. X400).

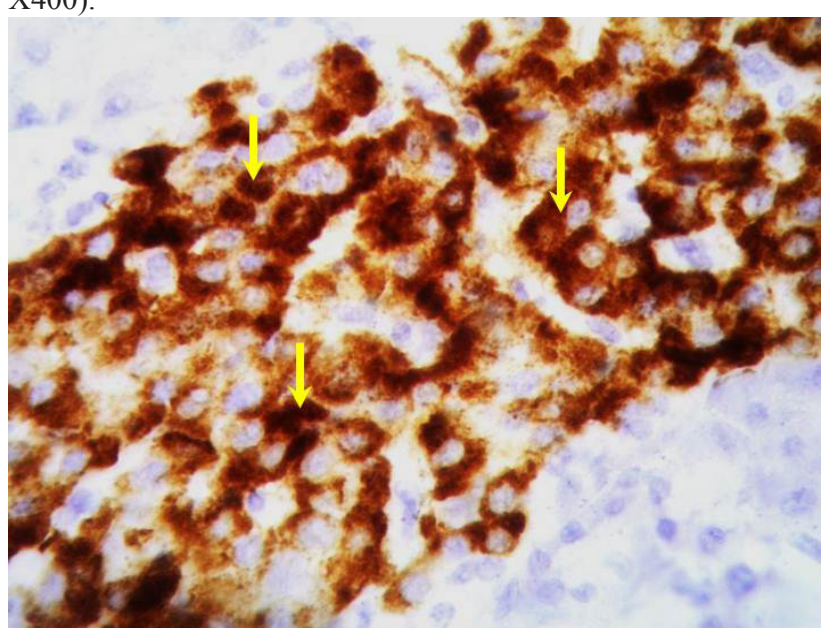

Fig. 29: A photomicrograph of the pancreatic tissue of withdrawal group IV a (treated with orlistat $30 \mathrm{mg} / \mathrm{kg}$ for 8 weeks followed by 8 weeks without treatment) showing strong cytoplasmic expression for insulin in nearly all beta-cells (arrow).

(immunostaining for insulin with counter stain hematoxylin $\mathrm{X} 1000$ ). 


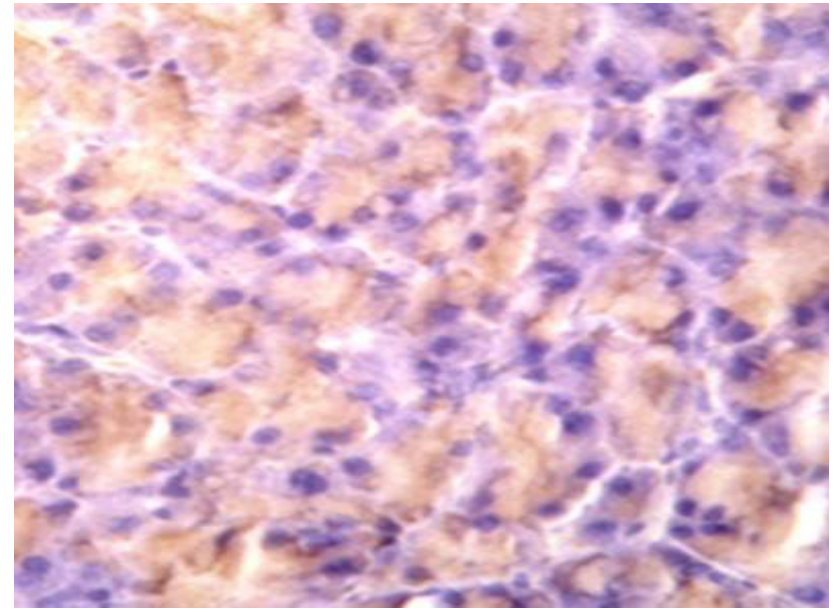

Fig. 30 : A photomicrograph of the pancreatic tissue of withdrawal group Iv b (treated with orlistat $40 \mathrm{mg} / \mathrm{kg}$ for 8 weeks followed by 8 weeks without treatment showing weak cytoplasmic expression for caspase- 3 in the acini (arrow).

(immunostained for caspase-3 with counter stain hematoxylin $\mathrm{X} 400)$..

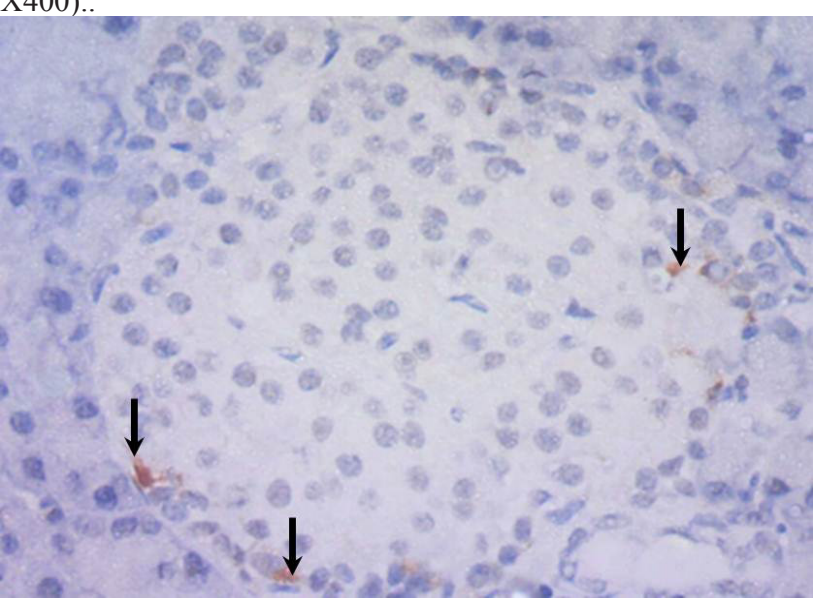

Fig. 31: A photomicrograph of the pancreatic tissue of withdrawal group IV b (treated with orlistat $40 \mathrm{mg} / \mathrm{kg}$ for 8 weeks followed by 8 weeks without treatment showing positive cytoplasmic expression for iNOS in few peripheral cells of Islets of Langerhan,s (arrow).

(immunostained for caspase-3 with counter stain hematoxylin X400)..

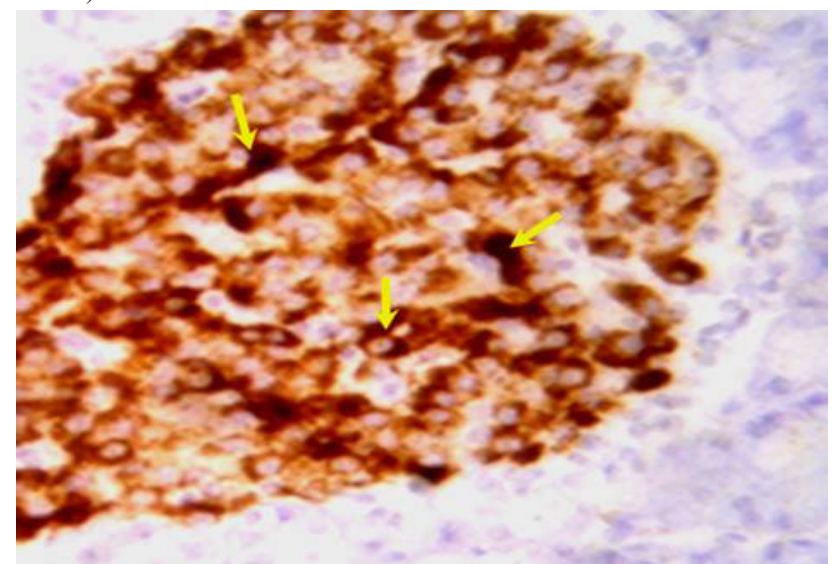

Fig. 32: A photomicrograph of the pancreatic tissue of withdrawal group IV b (treated with orlistat $40 \mathrm{mg} / \mathrm{kg}$ for 8 weeks followed by 8 weeks without treatment showing positive cytoplasmic expression for insulin in nearly all beta cells (arrows). (immunostaining for insulin with counter stain hematoxylin $\mathrm{X} 1000)$.

\section{DISCUSSION}

Obesity is a significant health problem that is growing in prevalence ${ }^{[12]}$. Orlistat (Xenical; Roche, Basel, Switzerland), an inhibitor of pancreatic lipases that limits the intestinal absorption of dietary fat, has proven effective in augmenting weight loss $^{[13]}$. Currently, orlistat is the only FDA (Food and Drug Administration) approved drug for long term management of obesity ${ }^{[14]}$. It has been reported that there has been an association between the use of orlistat and development of pancreatitis in some cases clinically with no evidence of biliary disease or alcohol consumption ${ }^{[15]}$. This study is concerned with the description of structural changes in rat pancreas following orlistat administration and whether these effects are dose dependent or not. Attempting to clarify the possible mechanisms beyond these changes histological, and immunohistochemical techniques are used.

In the current study, different structural changes were detected in the pancreatic tissue by light microscope in rats receiving 30 or $40 \mathrm{mg} / \mathrm{kg}$ of orlistat. In H\&E stained sections revealed that there were areas of vaculated acinar cells without inflammatory cellular infiltration in the pancreatic tissue of animals treated with $30 \mathrm{mg} / \mathrm{kg}$ orlistat. The pancreas of orlistat treated rats showed focal lesions in the pancreatic acini in the form of vaculolization of the acinar cells ${ }^{[16]}$.

In pancreatic tissues of the rats treated with 40 mg orlistat, there were more obvious focal areas of complete acinar cells destruction leaving empty spaces, replacement of acinar cells with fat cells and inflammatory cellular infilterartion. Cells resembling adipocytes were also observed in connective tissue septa between lobules.

The same results were observed in a previous study and were described as pancreatitis ${ }^{[17]}$. It was also found that there were dilated ducts with retained secretion in $30 \mathrm{mg}$ and $40 \mathrm{mg} / \mathrm{kg}$ treated groups. In accordance with our finding other study showed dilatation of the ducts in the parotid gland affected by hypercholesterolemia attributed to accumulation of the parotid secretion due to parotid tissue injury and dysfunction ${ }^{[18]}$. Dilatation and congestion of blood vessels was observed.

The vascular congestion and edema is due to accumulation of nitric oxide (NO). This $\mathrm{NO}$ is produced by the activity of NOS enzyme, which is involved in regulation of the rate of perfusion of the pancreatic microvasculature ${ }^{[19]}$.

In this study, morphological changes in some islets of Langerhans were found, in $40 \mathrm{mg} / \mathrm{kg}$ treated group in the form of congestion and inflammatory cellular infilteration. The same findings were observed in sodium taurocholate-induced acute pancreatitis ${ }^{[20]}$. 
The islets of Langerhans in $30 \mathrm{mg} / \mathrm{kg}$ treated groups appeared normal and hence we hypothesized that orlistat has a dose dependent effect our hypothesis was supported by what has been recently reported that patients ingesting orlistat have dose and diet dependent gastrointestinal adverse effects ${ }^{[21]}$

Caspase 3 is the key effector caspase involved in most apoptotic pathways. The present experiment had performed immunohistochemical localization of activated (cleaved) caspase 3 in rat pancreatic tissues.

During the execution of apoptosis cleaved caspase 3 is responsible, either partly or totally, for the proteolytic cleavage of a large number of proteins and for apoptosis associated chromatin margination, DNA fragmentation and nuclear collapse during $\operatorname{apoptosis}^{[22]}$.

In this study, it was found that orlistat administration caused expression of active caspase 3 in rat pancreatic tissues treated with $30 \mathrm{mg}$ and $40 \mathrm{mg}$.

Higher magnifications showed that the expression of activated caspase 3 , on the cellular level of acinar cells, showed a pattern of heterogeneity; some of the acinar cells had shown both cytoplasmic and nuclear expression while others showed only cytoplasmic immunoreactivity and that was observed in $40 \mathrm{mg} / \mathrm{kg}$ orlistat treated group while in $30 \mathrm{mg} / \mathrm{kg}$ treated group the acinar cells showed only cytoplasmic expression. In the present work we showed nuclear translocation of caspase 3 in some acinar cells. A previous study stated that Pro-caspase 3 may translocate from the cytoplasm to the nucleus and may be activated in both cellular compartments ${ }^{[23]}$.

By using confocal microscopy, there were nuclear localization of pro-caspase 3 in non-apoptotic cells. Active caspase 3 first appeared in the cytoplasm and was later observed in the nucleus. therefore, caspase-3 and perhaps other caspases are translocated into the nucleus by active transport which is required for apoptosis $^{[24]}$.

Immunohistochemical localization of TNF- $\alpha$ in rat pancreatic tissue was done in this study. Tumor necrosis factor- $\alpha$ (TNF- $\alpha)$ is the prototypic member of a cytokine family that regulates essential biologic functions (e.g., cell differentiation, proliferation, survival, apoptosis) and a broad spectrum of responses to stress and injury. It is primarily produced by immune cells such as monocytes and macrophages, but it can also be released by many other cell types, including acinar cells ${ }^{[25]}$. In this study, there was positive immunoreactivity for TNF- $\alpha$ in some acinar cells treated with $40 \mathrm{mg} / \mathrm{kg}$ of orlistat. TNF- $\alpha$ and TNF receptors (TNFR-1/TNFR-2) were produced in rat pancreatitis, and acinar cells were able to synthesize and release the mediator in vitro ${ }^{[26]}$.
It was also found that some cells within connective tissue septa had shown positive immunoreactivity for TNF- $\alpha$ and those cells are most probably macrophages.

There was significant increased intrapancreatic expression of TNF- $\alpha$ mRNA and of protein product in mice with cerulein-induced pancreatitis. Activated immune cells such as macrophages infiltrating the pancreas were considered the most prominent source of the cytokine ${ }^{[27]}$.

Activation of macrophages can be explained by leakage of enzymes from dilated disrubted ducts. Specific pancreatic enzymes such as elastase, carboxypeptidase A, and lipase were shown to activate and induce TNF- $\alpha$ expression in a rat macrophage cell line ${ }^{[28]}$.

TNF- $\alpha$ exerts its proinflammatory actions mainly through the activation of different genes, including those for other cytokines, chemokines, cell adhesion molecules, cyclooxy genase 2 , and inducible nitric oxide synthase (iNOS) ${ }^{[29]}$. TNF- $\alpha$ is capable of stimulating acinar cell death through necrosis and/or apoptosis $^{[30]}$. In this study the immunoreactivity for TNF- $\alpha$ in rat pancreatic tissues treated with $30 \mathrm{mg} /$ $\mathrm{kg}$ of orlistat was negative and that can be explained as orlistat has dose dependent effect.

In this study there was positive immunoreactivity for iNOS in $30 \mathrm{mg} / \mathrm{kg}$ and $40 \mathrm{mg} / \mathrm{kg}$ treated groups in endothelial cells and cells at the periphery of islets of Langerhans. The acinar cells showed faint expression for iNOS. The role of $\mathrm{NO}$ in the pathogenesis of acute pancreatitis remains controversial. The proinflammatory cytokines activate the production of iNOS, resulting in overproduction of NO, which could promote pancreatic injury ${ }^{[31]}$. Other studies reported that, NO acts as a biological scavenger and inactivate reactive oxygen species (ROS), which protects pancreatic acinar cells and has also beneficial effects by inhibition of neutrophil accumulation and improvement of microcirculation ${ }^{[31]}$. The immunoreactivity for iNOS was detected in islet of Langerhans cells and iNOS is expressed in $\beta$-cells in acute pancreatitis ${ }^{[33 \& 34]}$.

To our knowledge it is the first time to show the effect of orlistat on the endocrine function of pancreas. In the current study Immunohistochemical detection of insulin in rat $\beta$ - cells of islets of Langerhan,s using anti-insulin antibody was done and found that administration of orlistat down-regulates insulin production.

Increased expression of islet iNOS causes excessive NO production and contributes to the dysfunction of $\beta$ - and $\alpha$-cells and inhibits insulin secretion $\left.^{[35} \& 36\right]$. Lipid stress and hyperglycemia, increased iNOS production in $\beta$-cells and resulted in 
cell dysfunction or cell death ${ }^{[37]}$. Lipases are involved in insulin secretion; pharmacological inhibition of lipase activity in $\beta$-cells impairs insulin secretion and this explained the decrease in the immunostaining of $\beta$ pancreatic cells ${ }^{[38]}$. Different preparations of $\beta$-cells exhibit lipase activities. Among these is the hormonesensitive lipase (HSL), which, in white adipocytes, is the critical enzyme that hydrolyzes triglycerides to fatty acid. Reduction of lipolysis activity inhibited $\beta$ cells insulin secretion ${ }^{[39]}$. In the present study it was found that the deleterious effects of orlistat on the pancreatic tissue were completely reversible after 8 weeks of withdrawal of low dose $30 \mathrm{mg} / \mathrm{kg}$ previously used for the same period.

A clinical case of acute pancreatitis due to orlistat treatment improved after stopping the drug which means that it could be reversible. Animal treated with high dose of orlistat $40 \mathrm{mg} / \mathrm{kg}$ showed residual Vacuolated acini, dilated ducts and inflammatory cell infiltration after stoppage of the drug.

This may be explained by the dose dependent nature of the effects ${ }^{[40]}$

\section{CONCLUSION}

It could be concluded that orlistat treatment may cause pancreatitis of varying degrees depending on the dose affecting both exocrine and endocrine pancreas as well.

Orlistat should be taken under medical supervision and follow up of symptom such as acute abdominal pain, disturbed blood sugar level should be taken in consideration.

\section{CONFLICT OF INTEREST}

There are no conflicts of interest

\section{REFERENCES}

1. Townshend T, Lake A. Obesogenic environments: current evidence of the built and food environments. Perspect Public Health. (2017) ;137:38- 44.

2. Sun Y, You W, Almeida F, Estabrooks P, Davy B. The Effectiveness and Cost of Lifestyle Interventions Including Nutrition Education for Diabetes Prevention: A Systematic Review and Meta-Analysis. J Acad Nutr Diet. (2017);117:404- 421

3. Johansson K, Sundstrom J, Neovius K, Rossner S, Neovius $M$ Long-term changes in blood pressure following orlistat and sibutramine treatment: a meta-analysis. Obes Rev (2010): 11:777 -91.
4. Kristensen M, Juul SR, Sørensen KV, Lorenzen JK, Astrup A. Supplementation with dairy calcium and/or flaxseed fibers in conjunction with orlistat augments fecal fat excretion without altering ratings of gastrointestinal comfort. Nutr Metab (Lond). (2017);14- 13.

5. Rian M N, Frank GS, Alexander JJ , Andreas E K, Louis MA, Alfons BA, Ger T R, Marguerite E I , André V, Cisca W, Hein G G. Impact of Global Fxr Deficiency on Experimental Acute Pancreatitis and Genetic Variation in the FXR Locus in Human Acute Pancreatitis PLoS One. (2014); 9: e114393.

6. Sarr BU (2004): Diseases of the pancreas: acutepancreatitis, chronic pancreatitis, neoplasms of the pancreas, Karger, Switzerland: 66- 70.

7. Kose M, Emet S, Akpınar TS, Ilhan M, Gok AF, Dadashov M, Tukek T: An Unexpected Result of Obesity Treatment: OrlistatRelated Acute Pancreatitis. Case reports in Gastroentrol (2015) 9 : 152- 155.

8. Anroop BN, Shery J. A simple practice guide for dose conversion between animals and human. J Basic Clin Pharm. (2016); 7: 27-31.

9. Bancroft JD, Suvarna KS, Layton C : Theory and practice of histological techniques. 7 th ed. Harcourt: Churchill Livingstone: (2012)126, 127, 417, 422 and 425.

10. Sarah P. Thayer, Marina Pasca di Magliano, Patrick W. Heiser, Corinne M. Nielsen, Drucilla J. Roberts, Gregory Y. Lauwers, Yan Ping Qi, Stephan Gysin, Carlos Fernández-del Castillo, Vijay Yajnik, Bozena Antoni, Martin McMahon, Andrew L. Warshaw \& Matthias Hebrok Hedgehog is an early and late mediator of pancreatic cancer tumorigenesis, Nature (2003): 425, 851- 856.

11. Adeyemi D, Komolafe OA, Adewole SO Histomorphological and morphometric studies of the pancreatic islet cells of diabetic rats treated with extracts of Annona muricata Folia morphologica (2010); 69:92- 100.

12. Chandler M, Cunningham S, Lund EM, Khanna C, Naramore R, Patel A, Day MJ. Obesity and Associated Comorbidities in People and Companion Animals: A One Health Perspective. J Comp Pathol. (2017); 17: 22- 26.

13. Bello M, Basilio-Antonio L, FragosoVázquez J, Avalos-Soriano A, Correa-Basurto J. Molecular recognition between pancreatic lipase and natural and synthetic inhibitors. Int $\mathrm{J}$ Biol Macromol. (2017); 98:855- 868. 
14. Kumar P, Bhandari U: obesity pharmacotherapy: current status. Excli J (2015) 14: 290- 293.

15. Napier S, Thomas M 36 year old man presenting with pancreatitis and history of recent commencement of orlistat case report. Nutr J (2006): 28: 5- 19 .

16. Elbakary RH, Bayomy NA Histological and immunohistochemical study of the effect of orlistat on the exocrine pancreas of adult female albino rat. The Egyptian Journal of Histology (2011): 34 : 302- 310.

17. Bello M, Basilio-Antonio L, FragosoVázquez J, Avalos-Soriano A, Correa-Basurto J. Molecular recognition between pancreatic lipase and natural and synthetic inhibitors. Int $\mathbf{J}$ Biol Macromol. (2017); 98:855 -868.

18. Mubarak R. The Effect of Hypercholesterolemia on the rat Parotid Salivary Glands (Histo pathological and Immunohistochemical Study). Cairo Dent J (2008): 24: 19 -28.

19. Panek J, Zasada J The role of nitric oxide (NO) in acute pancreatitis. Przegl Lek (2007)::495-497.

20. Kudari A, Wig JD, Vaiphei K, Kochhar SM, Gupta R, Yadav TD, Doley RP Histopathological Sequential Changes in Sodium TaurocholateInduced Acute Pancreatitis. JOP J Pancreas (2007): 8:564- 572.

21. Sangwai M, Sardar S, Vavia P. Nanoemulsified orlistat-embedded multiunit pellet system (MUPS) with improved dissolution and pancreatic lipase inhibition. Pharm Dev Technol. (2014):19:31 -41.

22. Khaksar MR, Rahimifard M, Baeeri M, Maqbool F, Navaei-Nigjeh M, Hassani S, Moeini-Nodeh S, Kebriaeezadeh A, Abdollahi M. Protective effects of cerium oxide and yttrium oxide nanoparticles on reduction of oxidative stress induced by subacute exposure to diazinon in the rat pancreas. $\mathrm{J}$ Trace Elem Med Biol. (2017);41:79- 90.

23. Luo M, Lu Z, Sun H, Yuan K, Zhang Q, Meng S, Wang F, Guo H, Ju X, Liu Y, Ye T, Lu Z, Zhai Z. Nuclear entry of active caspase- 3 is facilitated by its p3-recognition-based specific cleavageactivity. Cell Res. (2010);20:211- 222.

24. Ramuz O, Isnardon D, Devilard E, ChorafeJauffret E, Hasson-Xeri L Constitutive nuclear localization and initial cytoplasmic activation of endogeneous caspase 3 evidenced by confocal microscopy. Int Exp Pathol (2003): 84: 75 -81.
25. Hehlgans T, Pfeffer K (2005): The intriguing biology of the tumour necrosis factor- $\alpha$, tumour necrosis factor receptor superfamily: players, rules and the games. Immunology 115:1- 20.

26. Liang T, Liu TF, Xue DB, Sun B, Shi LJ. Different cell death modes of pancreatic acinar cells on macrophage activation in rats. Chin . Med J (2008); 19:1920 -4.

27. Rau BM, Krüger CM, Hasel C, Oliveira V, Rubie C, Beger HG, Schilling MK Effects of immunosuppressive and immunostimulative treatment on pancreatic injury and mortality in severe acute experimental pancreatitis. Pancreas, (2006): Aug; 33(2):174- 83.

28. Zhao Y, Wang H, Lu M, Qiao X, Sun B, Zhang W, Xue D: Pancreatic Acinar Cells Employ miRNAs as Mediators of Intercellular Communication to Participate in the Regulation of PancreatitisAssociated Macrophage Activation. Mediators Inflamm (2016);

29. Genovese T, Mazzon E, Di PR, Muia C, Crisafulli C, Malleo G, Esposito E, Cuzzocrea $\mathrm{S}$ Role of endogenous peroxisome proliferators activated receptors alpha (PPAR- $\alpha$ ) ligands in the development of acute pancreatitis induced by cerulean. Immunology (2006): 118:559- 570.

30. Kempuraj D, Twait EC, Williard DE, Yuan Z, Meyerholz DK, Samuel I The novel cytokine interleukin-33 activates acinar cell proinflammatory pathways and induces acute pancreatic inflammation in mice. PLoS One (2013): 8:e56866.

31. Rahman SH, Ammori BJ, Larvin M, McMahon MJ Increased nitric oxide excretion in patients with severe acute pancreatitis: evidence of an endotoxin mediated inflammatory response. Gut. (2003): (52): 270-274.

32. Dobosz M, Hac S, Mionskowska L, Dymecki D, Dobrowolski S Organ microcirculatory disturbances in experimental acute pancreatitis. A role of nitric oxide. Physiol Res (2005): 54: 363-368.

33. Keklikoglu $\mathrm{N}$ Inducible nitric oxide synthase immunoreactivity in healthy rat pancreas. Folia Histochem Cytobiol (2008): 46:213 -7.

34. Qader SS, Ekelund M, Andersson R, Obermuller S, Salehi AAcute pancreatitis, expression of inducible nitric oxide synthase and defective insulin secretion. Cell Tissue Res (2003): 313:271- 9. 
35. Muhammed SJ, Lundquist I, Salehi A Pancreatic $\beta$-cell dysfunction, expression of iNOS and the effect of phosphodiesterase inhibitors in human pancreatic islets of type 2 diabetes. Diabetes Obes Metab (2012): 14:1010 -9.

36. Eckersten D, Henningsson R): Nitric oxide (NO) production and regulation of insulin secretion in islets of freely fed and fasted mice. Regul Pept (2012) 174:32 -7.

37. Bedoya FJ, Salguero-Aranda C, Cahuana GM, Tapia-Limonchi R, Soria B, Tejedo JR (2012): Regulation of pancreatic $\beta$-cell survival by nitric oxide: clinical relevance. Islets 4:108- 18 .
38. Garretson JT, Szymanski LA, Schwartz GJ, Xue B, Ryu V, Bartness TJ. Lipolysis sensation by white fat afferent nerves triggers brown fat thermogenesis. Mol Metab.(2016) ; 5:626- 34.

39. Mulder H, Yang S, Winzell MS, Holm C, Bo A, Inhibition of Lipase Activity and Lipolysis in Rat Islets Reduces Insulin Secretion. Diabetes (2004): 53: 122- 128.

40. Ahmad FA, Mahmud S. Acute pancreatitis following orlistat therapy: report of o cases. J Pancreas ( 2010) 11:61-6. 